натуральні виплати, наприклад харчування, знімання житла тощо, то в будь-якому випадку має виплачуватися грошова винагорода не менше $25 \%$ від установленої суми [5, с. 143].

По завершенню процесу навчання складаються випускні іспити для присвоєння професійної кваліфікації. Після складання випускного іспиту компетентним органом видається екзаменаційне свідоцтво. Навчальні підприємства отримують свідоцтво, яке містить дані про вид, тривалість та мету професійного навчання, а також відомості про отримані професійні знання, уміння і навички.

Після закінчення навчання здебільшого учні, що проходили навчання на великих підприємствах, залишаються працювати далі, але в ситуації, коли навчальне підприємство не стає постійним місцем роботи, учні, зазвичай, без значних труднощів працевлаштовуються за отриманою спеціальністю.

Отже, основними напрямами конструктивних динамічних перетворень у професійній освіті Німеччини є якість на всіх рівнях підготовки, інноваційний розвиток суспільства на засадах конкурентоспроможності освіти, забезпечення рівного доступу до всіх ланок професійної освіти завдяки створенню великої кількості освітніх програм. Унаслідок удалих заходів, спрямованих на модернізацію освітньої системи, одним із головних досягнень ФРН $є$ підготовка кадрів, які беруть безпосередню участь у створенні матеріальних благ та наданні послуг, якісно задовольняючи потреби населення.

\title{
Література
}

1. Абашкіна Н. В. Принцип розвитку професійної освіти в Німеччині/ Н. В. Абашкіна. - К. : Вища школа, 1998. - 207 с. 2. Абашкіна Н. В. Принципи розвитку професійної освіти в Німеччині : [монографія]/ Н. В. Абашкіна. - К. : Вища школа, 1998. - 207 с. 3. Липкина И. Н. Система образования взрослых в Германии : [учеб.метод. пособие]/ И. Н. Липкина, В. П. Тарантей. - Гродно : ГрГУ, 2001. - 104 с. 4. Berufsbildungsgesetz (BBiG) - Закон о профессиональном образовании Германии [Электронный ресурс]. - Режим доступа: http://www.gesetze-im-internet. de/bundesrecht/bbig_2005/gesamt.pdf. 5. Торопов Д. А. Обеспечение качества профессионального образования в Германии : дис... д-ра пед. наук / Д. А Торопов; РАО Ин-т педагогики и психологии профессионального образования. - М., 2005. - 301 с. 6. Романов С. П. Дуальная система инженерно-педагогического образования / С. П. Романов // Образование и наука. - 2007. - № 5. - С. 54-63.

УДК 373.3.016 (520)

Оксана Гудовсек

\section{ОСОБЛИВОСТІ ЗМІСТУ ОСВІТИ В ПОЧАТКОВІЙ ШКОЛІ ЯПОНІї}

Гудовсек О. А. Особливості змісту освіти в початковій школі Японії.

У статті проаналізовано особливості навчання в сучасній початковій школі Японії. На основі аналізу змісту початкової освіти виокремлено найважливіші його складники, розкрито специфіку навчальних предметів. Визначено, що важливе місце у змісті освіти японських початкових шкіл займає моральне виховання, а також позакласна виховна робота, участь дітей у національних святах.

Ключові слова: зміст, початкова школа, навчання, моральне виховання, учні, програма. 
Гудовсэк О. А. Особенности содержания образования в начальной школе Японии.

В статье проанализированы особенности обучения в современной начальной школе Японии. На основе анализа содержания начального образования выделены важнейшие его составляющие, раскрыта специфика учебных предметов. Определено, что важное место в содержании образования японских начальных школ занимает нравственное воспитание, а также внеклассная воспитательная работа, участие детей в национальных праздниках.

Ключевые слова: содержание, начальная школа, обучение, нравственное воспитание, ученики, программа.

Gudovsek O. A. Features of the content of education in primary schools in Japan.

In the article analyzes the features of training in modern elementary school Japan. Based on content analysis of primary education highlighted its most important components, is disclosed specifics school subjects. It was determined that an important place in the educational content of Japanese elementary school occupies moral education, as well as extracurricular education work, the participation of children in national holidays.

Key words: content, elementary school, education, moral education, schoolchildren, program.

Сучасна світова освіта складається 3 великої кількості національних освітніх систем, що різняться за своїми культурними традиціями, за рівнем цілей і завдань, а також за якісним станом освіти. Водночас прагнення подолати в освіті професійну замкненість і культурну обмеженість характерне для світового співтовариства. У зв'язку 3 цим стає важливим об'єднання зусиль всіх зацікавлених країн у пошуку відповідей на питання, звернені до змісту освіти, і їх осмислення в цілях визначення власних орієнтирів. Однак накопичений досвід не завжди стає надбанням інших країн, що певною мірою гальмує розвиток єдиного освітнього простору.

Зміст освіти - основний складник освітньої системи. У ньому в узагальненій формі відображається досягнутий суспільством рівень культури, соціальний досвід, який передається наступному поколінню для його збереження й подальшого розвитку. Соціально-економічні відносини, рівень розвитку науки, виробництва, техніки - це основні чинники, які вносять певні корективи в зміст освіти, що має відповідати соціальному замовленню. Провідну роль у визначенні змісту освіти відіграють мета та завдання, які ставить суспільство перед школою.

Проблемами змісту освіти займалося чимало педагогів, дослідників, наукових діячів. Так, у педагогічній та науковій літературі визначено термін «зміст освіти» та розкрито його суть (Ю. Бабанський, М. Ярмаченко, Г. Гессен, В. Лєдньов, І. Лернер, М. Скаткін, Л. Пермінова та інші). Зокрема, В. Лєдньов вважає, що зміст освіти потрібно аналізувати як цілісну систему. Значний внесок у створення концепції змісту освіти зробили М. Скаткін, І. Ларнер, В. Краєвський, які на основі аналізу соціального досвіду виокремили елементи змісту освіти. Суттєвий внесок у вивчення дидактичних засад змісту освіти за кордоном зробили Г. Дмітрієва, А. Ліферова, О. Піскунова та інші дослідники. Японії.

Мета статmі - розкрити особливості змісту освіти сучасної початкової школи

Сучасна система початкової освіти Японії склалася ще в II половині XIX століття за зразком країн Заходу та США. Однак вона не копіює їх, а є унікальним поєднанням національних та західних педагогічних ідей. 
За своїм змістом освіта в Японії особлива. Вона побудована за формулою «6-3-3-4». Школи у країні діляться на три ступені: початкова школа (сьогакко), середня школа (тюгакко), старша школа (котагакко). Початкова школа є обов'язковою та безкоштовною. У ній навчаються діти 3 першого по шостий клас. 3 сьомого по дев'ятий клас японські школярі відвідують безкоштовну середню школу першого ступеня. Наступні три роки діти мають можливість займатися у старшій школі другого ступеня. Відвідування такої школи $\epsilon$ необов'язковим, однак 45\% учнів отримують повну шкільну освіту, що надає їм змогу продовжити навчання в коледжі (2 роки) або університеті (4 роки). Загалом курс шкільної освіти в країні займає 12 років, половина якого припадає на початкову школу (через складність вивчення рідної мови). Навчання в старшій школі та в університетах завжди платне, однак в державних навчальних закладах воно значно дешевше.

Навчальний рік у японських школах розпочинається в квітні. Це пов'язано з тим, що в цей період у країні розквітає сакура (символ японської культури), тобто наступає весна. Завершується навчання в березні. Варто відмітити, що останнім часом в країні посилився рух за перенесення початку навчального року на 1 вересня, як $\epsilon$ в більшості країн Свропи. Однак, поки що він не знайшов значної підтримки у японського населення.

Особливість шкільної освіти в Японії в тому, що навчальний рік поділений на три триместри 3 сорокаденними літніми канікулами в липні та серпні, двотижневими зимовими - в кінці грудня та десятиденними весняними. Саме на весняних канікулах відбувається переведення дітей з класу до класу. Діти відвідують школу 240 днів на рік.

Японська початкова школа - це масовий безкоштовний навчальний заклад, що підпорядковується муніципалітетам. До таких закладів, як і в Україні, приймають дітей, яким виповнилося шість років. Однією 3 умов зарахування до першого класу $є$ володіння основами арифметики та вміння читати хірагану та катакану (японські складові абетки). Згідно 3 Державним стандартом, затвердженим Міністерством освіти i науки Японії, уроки в початковій школі зазвичай розпочинаються о 8 годині 15 хвилин, коли всі учні шикуються перед школою i слухають гімн Японії, а також віддають шану державному прапору. За півгодини розпочинаються заняття. Щодня учні відвідують 4-6 уроків, причому одна академічна година, так як і в Україні, триває 45 хвилин, між кожним уроком 10 хвилин перерви. Після третього уроку на великій перерві (50 хвилин) учні обідають -〈кю сьоку» (給食). Потім вони відвідують решту уроків, зазвичай це предмети варіативного складника «токубетсу кацудо» (特別活動). Після закінчення занять учні впродовж 10-15 хвилин прибирають шкільні приміщення.

У японській початковій школі класи бувають досить наповненими (до 45 учнів), а оскільки на уроках має бути контроль за кожним учнем, то урок можуть проводити два вчителі [7, с. 209]. Крім того, з метою кращої організації навчального процесу, дітей ділять на групи (хани). Склад таких груп змінюється кожні дві години. Це дозволяє учням стати більш відповідальними, сприяє набуттю широкого спектру комунікативних умінь та навичок.

Міністерством освіти та науки Японії та Радою 3 програм навчання розроблено «Курс навчання», обов’язковий для початкової школи. Цей документ відграє значну роль у підтримці єдиних Державних стандартів освіти. Він містить перелік обов'язкових предметів, програму позашкільної діяльності та програму з морального виховання.

Програма початкової школи спрямована на отримання дітьми збалансованих знань 3 основних предметів (японська мова, математика (арифметика), музика, мистецтво і ремесло, природознавство, домашня економіка, фізкультура, норми суспільної поведінки). 
Значне місце в навчальному плані початкових шкіл займає вивчення японської мови. На уроках рідної мови учні читають оповідання, обговорюють їх, вчаться грамотно висловлювати свої думки, а також практикуються у написанні ієрогліфів. Засвоєння ієрогліфіки становить значні труднощі для дітей, і тому вироблення навичок письма і читання вимагає багато часу і зусиль. На японську мову в початковій школі відводиться 7-9 годин на тиждень, що становить 35-36\% всього навчального часу. По закінченню початкової школи учні повинні знати 1006 символів кандзи та понад дві тисячі символів державного переліку.

Математиці (арифметиці) належить друге місце в навчальному плані початкової школи. В 1-2 класах на їі вивчення відводиться 3-5 годин на тиждень, а в 4-6 класах - 6 годин. В японських школах застосовують особливі форми та методи навчання дітей арифметичним діям, зокрема, уже в 1 класі вивчають множення багатоцифрових чисел за допомогою методу малювання та перетину рисочок.

Молодші школярі вивчають також курс природознавства, який поєднує елементарні знання з біології, хімії, геології і фізики. На уроках з суспільствознавства діти отримують комплексі знання 3 географії, історії, етнографії, знайомляться 3 краєзнавчим матеріалом. Позакласна, або так звана «суспільна діяльність» передбачає проведення різноманітних шкільних церемоній, літературних вечорів, виставок дитячих робіт, спортивних змагань, екскурсій, відвідування театрів, музеїв тощо.

Велике значення японська школа надає праці. Згідно з навчальними планами у початковій школі викладають два предмети, пов'язані з працею: «Малювання і ручна праця» та «Домоводство». Протягом шести років на малювання i ручну працю відводиться 452 години навчального часу. Учням дається свобода для самовияву своїх ідей і здібностей. Вони мають навчитися малювати, вишивати, виготовляти корисні й красиві речі, елементарні механічні іграшки, а також уміти сприймати і оцінювати красиве. На уроках домоводства, на які в 5 і 6 класах відводиться по 70 годин, школярі оволодівають елементарними навичками приготування їжі, прибирання і прикрашання житла.

Відповідно до Закону про шкільну освіту та інших нормативних документів початкова школа в Японії зобов'язана розвивати дітей розумово, естетично, морально i фізично. Тому крім уроків фізичної культури, на які згідно з навчальними планами початкової освіти відведено 3 години на тиждень, молодші школярі в позаурочний час займаються в різноманітних гуртках та секціях. Серед улюблених видів спорту в пошані у японських дітей великий теніс, бейсбол, футбол, легка атлетика, плавання, а також національні види спорту.

Розвиткові естетичних умінь і навичок сприяють заняття естетичного циклу. Зокрема на уроках музики японських школярів учать грати на музичних інструментах, на уроках малювання діти оволодівають початковими навичками образотворчого мистецтва.

Окрім навчальних занять естетичне виховання в японській системі початкової освіти реалізується через велику кількість свят і урочистих подій, які відбуваються упродовж навчального року. Особливу увагу в початковій школі приділяють національним святам та традиціям. Зокрема, серед найулюбленіших свят дітей молодшого шкільного віку Японії $є$ : День дітей (Кодомо но Хай), День дівчаток (Хінамацурі). А серед традиційних японських фестивалів, до яких активно залучають дітей молодшого шкільного віку, найбільшу популярність завоювали: фестиваль, присвячений цвітінню сакури (ханамі); фестиваль снігу (цукімі), фестиваль зірок, фестиваль «семи трав», фестиваль запускання небесних ліхтариків, свято поминання предків тощо [4, с. 36]. 
Свята та фестивалі проводяться з урахуванням культурних і естетичних традицій японського народу і формують художній смак, яким так відрізняються японці. Вони заохочують дітей до активної діяльності, стимулюють ініціативу та креативність, формують власне естетичне ставлення до навколишнього світу.

Моральне виховання молодших школярів в Японії здійснюється як на уроках «Морального виховання» (один-три рази на тиждень) так і в позакласній діяльності. Міністерством освіти та науки чітко сформульовано п'ять етико-педагогічних правил, свого роду заповідей, які повинні дотримуватися педагоги початкової школи у вихованні підростаючого покоління:

1) моральне виховання - це не одностороннє навіювання норм, а спосіб життя;

2) моральне виховання спрямоване на формування певних навичок: самоаналізу своєї поведінки, думок і почуттів; здібності до самостійних рішень і дій; готовності відповідати за їх наслідки;

3) важливо навчити учня молодших класів усвідомлювати інтереси інших, свою залежність від суспільства і від оточення;

4) основна форма морального виховання - організація групової діяльності; критерій його ефективності - неодмінна участь усіх школярів початкових класів в роботі і чітке усвідомлення кожним своєї ролі;

5) необхідно навчити школярів сприймати проблеми групи як свої особисті, донести до їх свідомості, що закони і норми життя в групі і суспільстві, а також їх дотримання потрібні кожній людині [1, с. 87].

Окрім того, у Державному освітньому стандарті говориться, що: «основним принципом морального виховання $є$ обов'язок здійснювати його у всій діяльності школи. Отже, необхідний рівень морального виховання може бути досягнутий, якщо йому приділяється відповідна увага не тільки безпосередньо на уроках морального виховання, але на будь-якому іншому навчальному предметі i в позакласній діяльності» [2]. 3-поміж найважливіших моральних якостей, які потрібно формувати у молодого покоління, у документі визначено такі: повага до людської гідності і величі життя; гідність наступників унікальної традиційної культури, які здатні ії успадкувати і розвивати; готовність формувати і розвивати демократичне суспільство і державу; здатність робити внесок у створення мирного міжнародного співтовариства; здатність приймати самостійні рішення; високоморальні якості.

Формування зазначених якостей має сприяти успішному розвитку молодшого громадянина японської держави.

Програма морального виховання в Японії поділена на чотири напрямки (сфери): ставлення до себе; ставлення до інших людей, взаємовідносини 3 іншими людьми; ставлення до природи і до піднесеного (божественного початку); стосунки всередині груп, з групами людей і з суспільством в цілому.

У ній чітко відбиваються установки Міністерства освіти і науки на «освіту задля формування характеру», «засвоєння моральних якостей, бажаних 3 позиції держави», «створення основ цивільної моралі». Сучасний курс морального виховання передбачає усвідомлення молодшими школярами певних соціальних норм у вигляді моральних цінностей та формування групової свідомості. У першому випадку кожен учень повинен керуватися принципом рівноваги і гармонії, постійно тримати свої дії під контролем і не піддаватися емоціям; дотримуватися встановлених базових принципів повсякденного життя; вчитися приймати рішення без коливань, але бути при цьому впевненим у своїй правоті. Іншими словами, учні повинні відповідати за свої дії; займати активну життєву позицію, пам'ятаючи, що праця - головна цінність. У другому випадку молодші 
школярі повинні пишатися приналежністю до групи, співпрацювати один 3 одним, сприяти порядку й дисципліні в ньому.

У країні видається велика кількість підручників і навчальних посібників для вивчення предмета «Моральне виховання» [3]. Так, підручник з морального виховання для четвертого класу початкової школи називається «Дотоку алі хон», що можна перекласти як «Шлях чеснот». Книга містить 24 оповідання, кожне з яких присвячене певній темі, запропонованої для обговорення на уроках в класі. Однак моральне виховання в школі не спрямоване на навіювання учням моральних істин. Його метою є допомога дітям самостійно зрозуміти і засвоїти ті моральні цінності, які необхідні для гідного життя в суспільстві.

Виховній роботі в японській школі підпорядкований весь навчально-педагогічний процес. Прийнято вважати, що моральність формується не тільки в процесі виховання, але і під впливом усього, що оточує людину. Саме тому велика увага педагогами зосереджена на правильній організації шкільного життя. Кожен день в початковій школі починається і завершується п’ятнадцятихвилинною «класною годиною», під час якої вчитель має можливість підбадьорити учнів напередодні занять або підвести підсумки робочого дня. Ці організаційні моменти також використовуються для обговорювання питань дисципліни і взаємин між учнями в класі.

Особливістю японської системи початкової освіти $є$ те, що учні одну годину на тиждень займаються у різних гуртках. Вони можуть відвідувати кілька гуртків одночасно або переходити 3 одного в інший, але в будь-якому разі участь хоча б в одному 3 них $\epsilon$ обов'язковою. Шкільні гуртки в Японії $\epsilon$ різного профілю (від спортивних до культурологічних). Керувати їх діяльністю мають право лише дипломовані педагоги [6, с. 90].

У країні діє досить ефективна система дотримання дисципліни. Якщо в Законі 1972 р. про початкову та середню школу містилось положення про можливість фізичного покарання учнів у разі недотримання ними встановлених норм поведінки, то нині це $\epsilon$ неприпустимим. До учнів-порушників застосовуються інші форми покарання, зокрема директор школи має право тимчасово заборонити учневі відвідування занять або взагалі відрахувати його зі школи. Щоправда, відраховують лише тих учнів, які після численних попереджень продовжують порушувати дисципліну, пропускають заняття без поважних причин, ігнорують шкільні правила. Крім того, учням, які порушують дисципліну, забороняють брати участь у додаткових заняттях, шкільних урочистих заходах [5, с. 120].

У початкових школах Японії не прийнято публічно повідомляти про успіхи чи невдачі дітей. Інформація про це занотовується до особистого журналу вчителя, а подяка або зауваження повідомляються кожній дитині індивідуально. Публічно перед усіма учнями класу вчитель інколи може відзначити старанність окремих дітей [6, с. 98]. У Японії вважається, що всі учні можуть успішно засвоювати шкільну програму. І якщо хтось відстає, то йому радять бути уважнішим у школі і більше часу відводити на роботу вдома. Японські школи функціонують під гаслами: «Успіху добиваються невтомною працею», «Якщо відстаєш, наполегливіше працюй над собою». У школах панівним є принцип «Працювати на межі своїх можливостей».

Отже, японська система початкової освіти вважається оптимальною системою навчання та виховання молодших школярів, що дозволяє учням розкрити свої творчі здібності, стати самостійними та вихованими людьми, і може слугувати прикладом для української школи.

Перспективи подальших досліджень убачаємо у вивченні сучасного стану підготовки педагогічних кадрів для японської початкової школи. 


\section{Література \\ 1. Нурутдинова А. Р. Этико-эстетическое воспитание в Японии /}

А. Р. Нуругдинова // Педагогика. - 2006. - № 10. - С. 87 2. Салимова К. И. Общеобразовательная школа Японии в XX в. / К. И. Салимова // Педагогика. 2006.- №8. - C. 88-96. 3. Berque A. Les mots de l'educatoin japonaise (1). / A. Berque. Paris, 1998. 4. Sasaki M. Viewof of Today's Japan/ M. Sasaki. - ALC Press:Japanese Texbook Series - 1995 - 418 p. 5. 佐藤順 - (2004). 現代教育制度. - 東京: 学文社. 6. 梅木 松助 (1994). 教育学概説. -- 東京: 学芸図書酋或更. 7. 真野宮雄、増田實 (1994). 現代教育 概説. 一東京: 学術図書出版.

УДК 37.014 .5

Ганна Давиденко

\section{УПРОВАДЖЕННЯ ІНКЛЮЗИВНОЇ ОСВІТИ У ВЕЛИКІЙ БРИТАНЇ: ПРОБЛЕМИ, ШЛЯХИ РОЗВ'ЯЗАННЯ}

Давиденко Г. В. Упровадження інклюзивної освіти у Великій Британії: проблеми, шляхи розв' язання.

У статті представлено результати аналізу основних проблем інклюзивної освіти у Великій Британії. Розглядаються перешкоди на рівні урядової діяльності, місцевої влади та місцевих громад. Особливу увагу приділено аналізу стану справ у системі шкільної освіти та пошукам шляхів подолання визначених перешкод у доступі до освіти.

Ключові слова: інклюзія, спеціальна освіта, система освіти.

Давиденко А. В. Внедрение инклюзивного образования в Великобритании: проблемы, пути решения.

В статье представлены результаты анализа основных проблем инклюзивного образования в Великобритании. Рассматриваются препятствия на уровне правительственной деятельности, местных властей и местных общин. Особенное внимание уделяется анализу состояния дел в системе школьного образования и поискам мер для преодоления препятствий в доступе к образованию.

Ключевые слова: инклюзия, специальное образование, система образования.

Davydenko H. V. The Implementation Of Inclusive Education In Great Britain: Obstacles, Future Challenges.

The results of analysis of basic problems of inclusive education in Great Britain are presented in the article. Obstacles are examined at the level of governmental activity, local authorities and local communities. The special attention is paid to the analysis to the state of businesses in the system of school education and searches of measures for overcoming of the obstacles in access to education.

Key words: inclusion, special education, system of education.

За законом будь-яка людина має право на визначення та реалізацію своїх соціальних прав.

Мальтійська декларація, прийнята на Конференції з доступу до соціальних прав у 2002 році, містить заклик до урядів і провідних сил суспільства розвивати та зміцнювати політику, яка сприяє доступу до соціальних прав.

Соціальні права - це одна 3 основних концепцій, на яких у XX столітті була побудована нова Європа. Проте й досі окремі 3 прав, визначених Європейською 